\title{
Charlotte Lucas's Practical Approach to Marriage and the Conditions of Women of Her Society in Jane Austen's Pride and Prejudice
}

\author{
Salma Haque \\ Department of English Language and Literature International Islamic University Chittagong Near Zia Smriti \\ Park, Chittagong, Bangladesh
}

\begin{abstract}
Jane Austen's novel Pride and Prejudice has several minor characters which are realistically portrayed. Charlotte Lucas is one of them. She is the eldest daughter of Mr. and Mrs. Lucas and is portrayed as a victim of her society. The dominant theme of this novel is marriage and is the only hope for her as she is a realist. She has plain appearance and is not in a position to disregard social conventions. Hence, she has practical good sense and a practical view of matrimony. Her marriage with Mr. Collins is not self-deception as she marries with her eyes open. For this reason, she does not consider her marriage a mistake though it is loveless. She is a fictitious character, but we should remember that Austen's characters are from real life. Charlotte's marriage is symbolic showing the financial insecurity of marriageable girls in her times. Therefore, her inability to disregard the existing social code needs to be judged from the viewpoint of $18^{\text {th }}$ century England. However, we cannot overlook her as a character who has admirable qualities. She draws mixed reactions. Some find her a moral failure and some appreciate her decision to marry Mr. Collins for financial security. Through her character, the agonies of unmarried women, their yearning for marital safety are exhibited in this novel. This paper focuses on the grounds for Charlotte's decision to marry Mr. Collins, the conditions of women of her society and her likeable qualities which save her marriage and individualize her.
\end{abstract}

Female characters are always core of Jane Austen's novels. In her Pride and Prejudice there are many female characters who fascinate many researchers. Some works talked about Charlotte Lucas and there are different voices from different critics about her. Weinsheimer $(1972,404)$ criticizes her for her interest in the establishment than the real happiness in marriage and also of her self-deception. However, Newton $(1981,11)$ argues that she was also the victim of her society. Tanner $(1986,108)$ also agrees that we should sympathize with her instead of blaming her. But their studies are not detailed and have not touched her good sides. Though women of Charlotte's society had lower social status than men, it does not mean there were no intelligent, sensible women. Austen also applies more positive term to her. So, this paper aims to show how realistically she represents the deplorable conditions of the marriageable women of her society and how she individualizes herself among her contemporaries with her good attributes.

Charlotte Lucas is past the romance as she is twenty-seven years old. The oldest of several children in the Lucas family she is introduced to the reader as "... a sensible, intelligent young woman ..." (18). We can know about her main characteristics in the above description. Her attitude to marriage is very important, as she shows an entirely materialistic view of marriage like her contemporaries. But she is utterly unlike the other spiteful girls of her society and a good human being. The deeper overtones of the theme emerge when she agrees to marry the ridiculous Mr. Collins. The insecurity of a single woman and the money-minded society are the dominant considerations which have formed her attitudes towards marriage, but as she has a significant feeling of life and reality, she finds her place in the plot.

During her time, women had to marry undesirable partners for financial reasons. In the words of Ian Watt: "Newspapers carried on marriage marts, with advertisements offering or demanding specified dowries and jointers, and young girls were driven into flagrantly unsuitable marriages on the grounds of economic advantage" (Watt, 142-3). In her society a woman's role was clear and simple. Her husband or father defined her position in life; she was expected to be modest, submissive and almost totally unable to think independently. Pride and Prejudice is also about the social conventions of the time, and the role of women in society as well as the causes of their subjugation and humiliation. The first sentence of the novel also highlights the importance of marriage in it: " . . a single man in possession of a good fortune, must be in want of a wife" (5) which ironically means that a single woman must be in want of a husband.

In Pride and Prejudice Charlotte Lucas is an important minor character whose physical description is not given and her dialogues are also limited. But we can judge her on the basis of her limited communication 
with other characters. And these dialogues inform us of her (1963), rationale for her actions, thoughts, feeings as well as her intentions.

The first quality of her character, which we note at the very outset and which continues to exhibit it self throughout the good nature which does not disappear even after her marriage. She also appears to be very sensible from the beginning of the novel. At the first ball she does not chase two eligible bachelors, Mr. Bingley and Mr. Darcy though they are the centerpieces to all marriageable women. It indicates that despite being weak in her position she never tries to chase them or any rich bachelor as she is not a flirt like her contemporaries. But we see the vulgar behavior of the upper-class Caroline Bingley who shamelessly tries to draw the attention of Mr. Darcy on several occasions. She also shows her jealousy by trying to discredit Elizabeth in Mr. Darcy's eyes at the ball. When Mr. Bingley dances with Charlotte, she does not want to draw his attention towards her because she notices his feelings for Miss Jane Bennet, the sister of her friend Elizabeth. She does not want to compete with beautiful Jane for she is conscious of her own plain looks and does not consider herself to be Jane's equal in terms of Mr. Bingley's attention to her when he dances with two of them. It means she does not in the least feel jealous of Jane's luck; rather she has self-awareness of her limitations and broadmindedness to accept her fate like other girls, whereas Caroline gets mean with Darcy when he gets attracted to middle class girl, Elizabeth. Thus, Charlotte proves that she is never jealous of the favourable luck of any familiar girl and has ample self-knowledge. She is also forgiving about Mr. Darcy's pride when the Bennet house his pride is a matter of serious discussion. We can find her of a very practical by nature when she claims that Darcy's pride does not offend her as there is an excuse for it.

Charlotte sincerely cares for her intimate friend Elizabeth and Jane and gives necessary and prudent advice to Eliza as she is a keen observer. She is also an acute and rational person. We cannot but remember her opinion to Elizabeth about Jane's inexpressive nature when she says: "Bingley likes your sister undoubtedly; but he may never do more than like her, if she does not help him on" (21). Her astute remark foreshadows Bingley's temporary separation from Jane. She is sensible that Bingley's love does not grow without encouragement from Jane. She wants to see Jane as Mrs. Bingley, but his sister, Caroline, persuades her brother to remove him from Jane's path. Despite being Jane's friend she can think of shattering the dream of an innocent girl which is unthinkable to middle-class Charlotte. Elizabeth, on the other hand, does not think that Jane should change her habits at all. Thus, we see that though Charlotte ". . . shares Elizabeth's taste for raillery and social generalization ...." ( Mudric, 103) “. . . in an important respect she differs highly from Elizabeth- though Elizabeth herself does not know this fact" (Wright,106) by embodying the opposite views of marriage. So, Charlotte's " . . . relationship with Elizabeth establishes the fact that she has intelligence, sensibility and integrity" (Marcus,276) and her perception about Jane comes true when later on we read Mr. Darcy's letter in chapter 35, where he writes about Jane's feeling; she did not invite them by any participation of sentiment"(163). He also admits that he was responsible for preventing Mr. Bingley from marrying Jane, as on observing Jane and Bingley together he was convinced that Jane was very reserved and it did not appear to him that she was in love with Bingley.

Although Charlotte values her friendship with Elizabeth very much, she needs financial security above all,as she is not valued in her materialistic society and has no reasonable place there. Moreover, her father, Sir. William Lucas is not well-connected with the landed gentry. So in her solitude she suffers and she does not want to prolong her sufferings as she is compelled to observe her painful situation. She does not want to miss any golden opportunity because of her limited choice. Therefore, she emerges as a practical character repeatedly.

Marriage is inevitable in Charlotte's society and it will determine her fate as well as the fates of the marriageable girls. For this reason, Mrs. Bennet, the mother of Elizabeth, has also only one purpose in life, to marry her daughters to rich persons. It is much more than happiness which will bring financial security. Hence, Charlotte says to Elizabeth: "Happiness in marriage is entirely a matter of chance" (22). This line reflects her limitations and her practical nature. In the words of Lewis: "It is wrong to marry for money, but it is silly to marry without" (Lewis, 72). Consequently, it is not a wrong decision as she will be judged by money and comfort in her society.

It is clear from the rest of the novel that most of the characters would agree with Charlotte whose: “. . . attitude to the institution is straightforward.( Milligan,:46). In eighteenth-century England women were taught that ". . . it was a sign of weakness to hope too much ..." (Cecil, 22). So, she does not want to have higher expectations and decides rationally to accept Mr. Collins, as she is unimportant in her circle of acquaintances except him. Though “. . . Mr. Collins has proposed to Charlotte on the sly .. ." (Craik, 63), she is not desirous of concealing the fact from Elizabeth. and herself unfolds the matter to her friend. Her announcement gives us the idea of her helplessness, as she cannot complain about her sufferings for her desire and social reality are at odds.

Charlotte gives Elizabeth the reason for accepting Mr. Collins's proposal. She is usually so sensible that Elizabeth is shocked and hurt by her friend's decision and cannot suppress her amazement: "Engaged to Mr. Collins! my dear Charlotte,-impossible" (105). But Charlotte loses some of Elizabeth's good opinion and is 
resolved to marry Mr. Collins as she is not romantic and asks for a comfortable home. This decision shows us her unshaken resolution as well as her pitiable condition. The intelligent Elizabeth fails to realize her predicament but Brown (1976) suggests that Charlotte Lucas is much aware of the severe limitations of her marriage. At twenty-seven, the rather plain Charlotte has little prospect of marriage in a society in which the option of work is not open to women. Elizabeth is shattered by the news as she has never taken seriously enough the cynicism towards marriage expressed by Charlotte in chapter six: "Happiness in marriage is entirely a matter of chance" (22). Elizabeth cannot think of marrying a man she cannot love and respect and fails to realize that ". . . the mercenary view of marriage is proclaimed by many of her people, and practiced by even more" (Chapman, 191). At one point of time when she concerns for Charlotte's marriage, her sister, Jane comforts her and defends Charlotte: "Remember that she is one of a large family; that as to fortune, it is a most eligible match" (114). However, from a modern view, it appears that Elizabeth's marital view is correct. But even in today's time some people still marry for money, and sometimes it is the key to widening gaps among couples. Even Mr. Bennet, father to Elizabeth, considers Charlotte as foolish as his wife and his daughter. His statement is illogical as he fails to see the weak position of Charlotte. Therefore, her acceptance of Mr. Collins's proposal is not complete disgrace but acceptance of harsh reality. Since she is not infatuated by Mr. Collins, she will not be disheartened to discover his oafish nature. As Mr. Collins will inherit the property of Mr. Bennet after his death for not having any male issue, Mrs. Bennet perceives Charlotte to be greedy of their property and thinks she is ". . . resolving to turn herself and her daughters out of the house, as soon as Mr. Bennet were dead"(109). She cannot understand that Charlotte marries for money but she is not heartless.

In Charlotte's society if a woman was seen to be unmarried at a certain age, she was not worthy of getting a husband in all her life. Hence, her determination to marry Mr. Collins despite her friend's disapproval, proves herself a strong-willed person. In this regard she is better than Mr.Darcy's friend, Mr. Bingley, who is amenable and gets separate from the eldest Bennet daughter, Jane, under the influence of his best friend Mr. Darcy. As Charlotte has strengths and weaknesses, she knew exactly what she was doing when she married Mr. Collins. She does not at all regret her marriage to him. If she remains with her family, she will be a financial burden on them and will cause them great worries. We are not baffled by the match because through her marriage we can feel the time of Charlotte Lucas specially the financial insecurity of marriageable women. We also see, Wickham that the villain of this novel is not willing to marry the youngest Bennet daughter, Lydia, unless her family repays his debt. He will marry her on condition that she will be willed one thousand pounds. Even Mr. Darcy's cousin, Mr. Fitzwilliam, informs Elizabeth about his intention of marrying any rich woman. Their avarice is normal considering the social situation of 18th century England. Actually, when Charlotte ". . . accepts Mr. Collins, we are for the first time made fully aware of some of the ugly realities underlying the stately social ballet" ( Daichess, 752).

By marrying Mr. Collins she cannot uphold her dignity as a woman but nobody can doubt her intelligence and instinctive goodness which do not diminish even after her marriage. Collins and Charlotte need to marry, Charlotte because if she does not she will become an old maid, and Collins because his patron, Lady Catherine de Bourgh, instructed him to. For them marriage is a market place where they must strive to make the best bargain they can in order to conserve or improve their status in life. Accordingly, it shows us that theirs is a 'marriage of convenience' for comfort and status; rather than love. Since in 18th century England, this sort of marriage was perfectly acceptable even expected, Charlotte proves that she is not an exception in her pecuniary society where men value a woman's looks before examining her character. So, Mr. Collins is tolerated and is accepted. Through her marriage she achieves what she wants-financial stability, status and independence by becoming a mistress of her own house. Even Mrs. Bennet pressurized her intelligent daughter, Lizzy, to accept foolish Mr. Collins as her daughter's husband for financial security. She also requested Charlotte to convince her daughter to accept his proposal.

In $18^{\text {th }}$ century England rejection for women was a far less obvious matter. Elizabeth rejected $\mathrm{Mr}$. Collins for his stupid nature and his wealth only, but Charlotte does not want to go against society as her situation was more complex and marriage had been long-delayed and there was no chance for her to bring dowry for her would- be-husband. Charlotte apprehends that marriage based on true love may not work because of financial security but in a loveless marriage at least money can save it. Her marriage is not ideal but she is able to escape social pressure and humiliation as well as social isolation.

She accepts the marriage proposal of Mr. Collins twenty-four hour after Elizabeth's rejection by scheming as her marriage will secure the only honourable provision for someone in her position. Her decision or behaviour is not improbable though this is not the way to success in marriage. As she lives in a mercenary world, she talks about the need to marry for money.

Austen has produced the character of Charlotte to be obedient to her parents. Since she was desperately in need of marriage, she could have eloped with Collins shamelessly like Lydia Bennet. But in reality she marries with the full consent of her whole family as they 'think it is a very acceptable alliance'. They are also relieved from their apprehension of Charlotte dying an old maid. Actually, her family's approval also shows the 
demeaning conditions of the middle class marriageable girls who lack 'fortune as well as good looks.' It seems as if their helplessness is general there and the family members of the victim can do nothing except watching and finally being satisfied with the marriage of their daughters anyhow. Despite knowing all about Mr. Collins's shortcomings and not being in love with him, Charlotte knows he can offer her a stable future, with a comfortable home and income, making it a practical match. So, her marriage is not a moral failure for the $18^{\text {th }}-$ century English society. Rather sacrifice for the sake of 'family' as well as 'society.' She has self-knowledge which her intelligent friend Elizabeth lacks up to a certain time. The relationship between these two characters (Charlotte and Mr. Collins) proves to the reader the consequences of placing practicality before romance which was not uncommon in the 18th century England.

Charlotte's marriage could have turned out much worse because of her ridiculous husband. But she works to save it as her good sense prevails after her marriage also. For this quality she refuses in silence to criticize her husband. She also does not offend anybody in her new life and well-behaved. On the other hand, upper-class Caroline and Mrs. Hurst are biting towards their contemporaries and lack appropriate dignity and style. In Charlotte's new 'life' she adapts to those around her and never complains against anybody as it provokes insolence. She always shows judgment and never breaks at the stupidity or pomposity of her husband because she is a woman of understanding and has self-restraint. She knows romantic love does not always make romantic marriage which sometimes ends up in not-so-romantic divorce. In the marriage of Elizabeth's sister, Lydia, we see that their romantic marriage will not last for the lack of tact and sensibility as she marries for uniform and his good looks. Even they face financial insecurity and have to beg for money to her two elder sisters, Elizabeth and Jane. But Charlotte knows that, when ecstatic passion fades, some couples feel cheated and declare their marriages bankrupt. In her case love does not exist and there is no question of getting disillusioned after her marriage as she expects nothing more out of marriage than financial stability and that is what she has got. As the wife of a clergyman she also gets respect from the parishioners.

Mr. Collins could have brought her to insanity. Her good humour and tact rather help to create a relaxed home. For these reasons, she never opposes him directly. She knows that Lady Catherine de Bourgh, her husband's patroness, matters very much on his life. She is sensible to realize that she must flatter that woman and pays regular courtesy visits to her house (Catherine's) as she understands her husband very well and wants to avoid any confrontation with him. She is unaffected by her indignities because in eighteenth-century England: "Women have been forced to seek their ends by means of coquetry and cunning . . ." (Wollstonecraft, 164).Thus, she keeps peace in her married life tactfully.

When Charlotte's father and sister come along with Elizabeth to her new 'home' nobody is given preferential treatment by her, rather she is very delighted to see her close friend proving her steady character, because before her marriage she requested Elizabeth to correspond with her and to visit her though she married Mr. Collins despite Elizabeth's disapproval. On the eve of her marriage she requested Elizabeth "Will you come and see me? (123)Elizabeth accepts her invitation and has "... spent six weeks with great enjoyment" (177) with her friend. Therefore, we see, she does not break her friendship with Elizabeth even after her marriage. Whereas Jane's friend Caroline forgot her (Jane) when she went away from Netherfield Park. She also left her house without any kind of leave- taking as her friendship with Jane was superficial. During Jane's stay at Caroline's house, she was not given a warm welcome and had to call her sister, Elizabeth, for comfort. Caroline's interest in sick Jane was shallow though she pretended concern for her. During Jane's stay in London, she could not 'see, or 'hear' from Caroline regularly who was also in the same place. Jane also expressed her frustration about Caroline's sham friendship to Elizabeth. Consequently, Charlotte's good nature is distinct from the contemporary girls.

When Elizabeth comes to Collins's house, he makes a display of his house, as if to remind Elizabeth of what she has missed as she rejected him. Whereas Charlotte manages to avoid the embarrassment of his pompous behaviour by pretending not to notice it, she cannot think of offending her husband and never undervalues him directly. However, she avoids him tactfully. If she tries to silence him, the situation will be bitter. So, she keeps up the pretence of a satisfactory marriage. She admits to Elizabeth that she encourages Collins to work in the garden because she refuses to create an unhealthy situation for her by quarrelling with him. In Wilson's (1985) words she takes refuge at the rear of the parsonage like Elizabeth's father Mr. Bennet who escapes to his library from his despised wife. Thus, Charlotte's behaviour is not uncommon to her society. Charlotte also does not underrate Elizabeth because of Elizabeth's unmarried status when she (Elizabeth) visits her(Charlotte) new 'home.' She also never tries to make Elizabeth regretful for not marrying Mr. Collins. We find this sensibility of Charlotte really admirable because after the marriage of Elizabeth's youngest sister Lydia, she insults her two elder sisters, Elizabeth and Jane, for their single status. Lydia behaves as if she defeated her elder sisters in the marriage market. But, Charlotte's marriage to Mr. Collins does not reveal herself as a proud person bent upon insulting unmarried marriageable women. After their marriage neither Collins nor Charlotte has changed. Though her family feels triumphant over Elizabeth's family, she is unboastful of her marriage. Rather she is composed before and after her marriage. Even after Lydia's elopement her husband, Mr. 
Collins, sends a humiliating letter to Lydia's father, Mr Bennet but Charlotte refrains from making any kind of comment on Lydia.

Charlotte knows that some loving wives fail to satisfy their husbands. But she has made a satisfactory adjustment to her conjugal life. In marriage, a woman and a man trust their souls to each other, each improves the other, but she does not try to improve his manners as she knows that some changes are impossible to achieve. So her active sensibility plays an important role in her contentment as well as comfortable settlement. There's is a loveless marriage and she is honest to admit it. As for both of them it is more a marriage of convenience, she is unworried about its lack of love.

No sensible girl desires a loveless marriage. But Charlotte's society forces her to this life and she has no self-pity as women of her time have only one route to self -improvement. They must marry for financial advantages, and to this object their time is sacrificed. For her abject submission, we feel for her, and for her good qualities we like her.

Passionate love occasionally fails to hold loving couples together for want of understanding between partners. For safeguarding a marital life at least one partner is expected to be mature. In their relationship, she makes up for her husband's silly nature and they do not have major rows as she is not hurting to her husband for making their marriage conflict-free. Actually, it is not the differences of opinion a marriage, but how a couple handles the differences that causes problems. Sometimes well-matched couple cannot solve problems for want of tact. In consequence, their relationship worsens. In Charlotte's case for her tact she saves her marriage and keeps relationships from developing irreparable breaches. In this sense, she is careful about her marriage and the news of her pregnancy makes us think about the stability of their marriage.

Pleasure is not the same as happiness. She may not get happiness but she gets pleasures by keeping her home tidy, whereas some perfect couples do not know how to get it. When Elizabeth visits Charlotte's house, she gets pleased to see her friend's small but neat house for which Lizzy gives credit as "The ladies in Miss Austen's novels, representing the smaller gentry and upper bourgeoisie, have little to do but to read poetry, retail gossip ..." (Trevelyan, 501) We see, she is not occupied with such vain things; rather spends time performing household chores sincerely. The simpering Caroline and overbearing Lady Catherine also reveal cultural poverty when they display their lack of interest in reading and music. But Charlotte does not lack intelligence though she has had to marry stupid Mr. Collins. She is practical and knows that her loveless marriage cannot take her good qualities from her. For these qualities she realizes harsh reality repeatedly and saves her marriage. Everybody was apprehensive about the permanence of her marriage. Even though before her marriage Mrs. Bennet, the mother of her intimate friend trusted that the match might be broken off, she proves them wrong by her sensibility, maturity and intelligence. Elizabeth also admits Charlotte's 'excellent understanding' but wholly rejects her friend's perceptions when she comes to know about Mr. Darcy's arrival at her house in her absence. She (Charlotte) explains Darcy's visit as a sign of his growing attraction to Elizabeth. Later Charlotte's suspicion comes true and she gets very delighted at the prospect of seeing Eliza as Mrs. Darcy. Contradictorily, Mr. Darcy's affluent aunt, Lady Catherine De Bourgh, schemes to prevent his marriage to Elizabeth. So we can easily see Charlotte's exceptionality in her society. When Elizabeth suffers from headache and refuses to see Mr. Darcy, Charlotte respects Elizabeth's decision by preventing her husband, Mr. Collins, from pressing her friend. Her genuine feelings for Elizabeth touch us deeply. Therefore, she displays that despite being mercenary she is not heartless. As Stephen suggests: “. . . good-manners are a sign that a person considers others as important as himself . . . in her society upper-class women lack these qualities" (Stephen, 194) which she possesses.

Though Elizabeth has intelligence, she has some flaws in her character and her judgment is faulty. After rejecting Mr. Darcy's proposal, she regrets and accepts him when is re-proposed. But Charlotte never regrets her marriage as she marries with ample self-knowledge.

Despite having admirable qualities, Charlotte rationally degrades herself by choosing a stupid husband but we have to remember that she does not have Elizabeth's boldness to reject material comfort, as her position is weaker than Elizabeth's. Actually, through Charlotte's character Jane Austen gives a picture of the reality that ordinary young women of her class would have to confront.

In this novel Charlotte is not the only one who opts for a loveless marriage. We see that ill-matched Bennet couple have to come to terms on the finding of mates for their five daughters.

Charlotte is not faultless, but a woman of inestimable qualities and a victim of her greedy society which has driven her into an unsuitable marriage. She never fancied herself as a suitable candidate at marriage market and felt pressurized to marry fast and felt as though the obnoxious fool, Mr. Collins, had been the only option. Since the story of the novel is about husband hunting by desperate marriageable girls for economic survival, we do not wonder at her marriage. Definitely, it is a marriage of financial gain or social elevation but we cannot deny her personal qualities which she has repeatedly shown and for them we cannot ignore her as a character and our final picture of her is not a farcical one. Moreover, we also excuse her as although society has considerably changed since Charlotte's time, some girls still marry for money. 
Considering all these arguments presented in this paper, it can finally be said that through the minor character of Charlotte Lucas, we can perceive the poor conditions of the marriageable daughters of her society for whom life is a matrimonial game as women in her society had no other option of business or profession open to them. Thus, she is a true reflection of her society but is different from the women, as there can be no two opinions about her good qualities which have all been present in her from the beginning till the end of the novel, saving her from degenerating into a comic, foolish character.

Notes: All quotations are from Jane Austen's Pride and Prejudice, London, Penguin Books Limited, 1998

\section{Works Cited:}

[1] Bloom, Harold, Jane Austen's Pride and Prejudice, New York: Chelsea House, 1986.

[2] Brown, Lloyd W, "The Business of Marrying and Mothering” in Jane Austen's Achievement, McMaster, Juliet (ed.), New York, Barnes and Noble Books, 1976

[3] Cecil, Lord David, Jane Austen: The Leslie Stephen Lecture, Cambridge, 1935.

[4] Chapman, R.W., Jane Austen, Facts and Problems, London: Oxford University Press, 1970.

[5] Craik, W.A., Jane Austen: Six Novels, Great Britain, Pimlico, 1968.

[6] Daichess, David, A Critical History of English Literature, New York, Ronald Press, 1960, Vol.2.

[7] Lewis, C.S, “ Two Solitary Heroines ” in Critics on Jane Austen, O Neil, Judith (ed.),George Allen \& Unwin (Publishers) Ltd. 1994.

[8] Marcus, Mordecai, "A Major Thematic Pattern in Pride and Prejudice" in Nineteenth-Century Fiction, XVI, California : California University Press, 1961.

[9] Milligan, Ian, Studying Jane Austen, England: Longman 1988.

[10] Mudric, Marvin, Jane Austen: Irony as Defense and Discovery, Princeton, Princeton University Press, 1952.

[11] Newton, J. L. Women, Power and Subversion: Social Strategies in British Fiction, 1778-1860, New York: University of Georgia Press, 1981

[12] Tanner, T. Jane Austen, Houndmills, Basingstokr, Hampshire and London: Macmillan Press Ltd., 1986

[13] Trevelyan, G.M., English Social History: A Survey of Six Centuries, London: Penguin Books Ltd., 1986

[14] Twentieth Century Interpretations of Pride and Prejudice: A Collection of Critical Essays, Rubinstein (ed.) New Jersey: PrenticeHall, 1969.

[15] Watt, Ian, The Rise of the Novel, Great Britain, Chatto \& Windus, 2000.

[16] Weinsheimer,J. "Chance and Hierarchy in Pride and Prejudice", ELH(1972):Vol.39.No,3,

[17] Wilson, Raymond, Pride and Prejudice by Jane Austen, London, Macmillan, 1985.

[18] Wollstonecraft, Mary, The Norton Anthology: English Literature, Seventh Edition, volume $2^{\text {nd }}$, New York: W. W. Norton \& Company, 2000

[19] Wright, Andrew. H: "Heroines, Heroes, and Villains in Pride and Prejudice" in Jane Austen's Novels: A Study in Structure, Chatto \&, Windus, London., 1961. 